\title{
Late Permian (Changsingian) ostracods of the Bellerophon Formation at Seis (Siusi) (Dolomites, Italy)
}

\author{
WOLFGANG METTE ${ }^{1 *} \&$ PARVANEH ROOZBAHANI ${ }^{2}$ \\ ${ }^{1}$ Institut für Geologie und Paläontologie, Universität Innsbruck, Innrain 52, 6020 Innsbruck, Austria \\ ${ }^{2}$ Islamic Azad University, Khorramabad Branch, Department of Geology, Iran \\ *Corresponding author (e-mail: Wolfgang.Mette@uibk.ac.at)
}

\begin{abstract}
Ostracod assemblages of the Upper Permian Bellerophon Formation at Seis near Bozen (South Tyrol, Italy) have been studied with respect to their taxonomy and palaeoecology. The investigations were concentrated on the Late Changsingian Casera Razzo Member which yielded five ostracod assemblages including more than twenty-four species. Twelve of these species are described herein and four species are new, including two species with strong affinity to taxa appearing in the Early Triassic. The lithofacies characteristics and low species diversity are suggestive of a protected shallow lagoonal environment with salinity fluctuations due to freshwater influx. Only four species are recorded from Late Permian localities outside of the Dolomites. This is due to the restricted environmental conditions which inhibited the immigration of more taxa from open shelf environments. J. Micropalaeontol. 31(1): 73-87, February 2012.
\end{abstract}

KEYWORDS: Ostracods, Late Permian, palaeoecology, palaeosalinity, Bellerophon Formation, Dolomites

\section{INTRODUCTION}

During the last decade ostracods from the Upper Permian and Lower Triassic have been reported from several sections in various parts of the world (e.g. Crasquin-Soleau et al., 1999; 2004; 2005; Crasquin-Soleau \& Kershaw, 2005; Crasquin et al., 2010a, b). Due to these studies the patterns of extinction and recovery of ostracods during the Permian/Triassic biotic crisis is understood much better now than it was a few years ago. Although the Bellerophon Formation had been the subject of intensive palaeontological research on various fossil groups, particularly with respect to the forminifera, there was very little known about the ostracods of this formation. Ostracods from the Bellerophon Formation were documented for the first time by Pasini (1981). The first detailed analysis of Late Permian and Early Triassic age ostracods from the uppermost part of the Bellerophon Formation and the lowermost Triassic part of the Werfen Formation was published by Crasquin et al. (2008). In the present study ostracods from a stratigraphically lower part of the Bellerophon Formation are described. Besides the species documented herein, there occur a number of other ostracod species which are not included here because of poor preservation and insufficient material. This suggests that the Bellerophon Formation may yield a greater number of hitherto unknown species.

\section{STRATIGRAPHY AND FACIES}

The Bellerophon Formation is an Upper Permian succession of fossiliferous limestones, dolomites, siltstones, sandstones, shales and evaporites indicative of shallow-marine, lagoonal and marginal-marine environments. It is distributed in the southern Alps from the Etschtal (western Dolomites) in the west to the Karawanken Mountains in the east. Evaporitic and dolomitic sediments which constitute the lower part of the formation are traditionally called the 'Fiemmazza Facies'. Dark-grey fossiliferous carbonates, deposited in shallow-marine and lagoonal environments of a broad and gently eastward-tilted carbonate ramp (Bosellini \& Hardie, 1973; Noé, 1987) occur in the upper part of the formation and are known as the 'Badiota Facies' (Accordi, 1957). According to subsequent research (Farabegoli et al., 1986; 2007) the upper Bellerophon Formation is subdivided into three lithostratigraphical units: the Casera Razzo Member, 'Ostracod unit' and Bulla Member. The exact biostratigraphical age of these units has always been a matter of discussion due to the extreme scarcity of conodonts and absence of ammonoids. At present the upper part of the Bellerophon Formation is dated by means of palynomorphs and a few conodonts that suggest a late Changsingian age (Pittau, 2001; Farabegoli et al., 2007).

The ostracods described here were recovered from an outcrop of the Casera Razzo Member in a gorge along the Weissenbach River (Rio Bianco) south of Seis (Siusi) (Fig. 1). The section consists of dark-grey fossiliferous wacke- and packstones ('Badiota facies') intercalated with marls, siltstones and fine-grained sandstones. According to Farabegoli et al. (2007) its thickness increases greatly from $12 \mathrm{~m}$ in the western Dolomites to more than $150 \mathrm{~m}$ in the Carnic Alps. In contrast to these data the Casera Razzo Member at Seis shows a total thickness of only $9 \mathrm{~m}$. At this outcrop the member consists of two lithostratigraphical units (parasequences 1 and 2) reflecting minor sea-level fluctuations (Fig. 2).

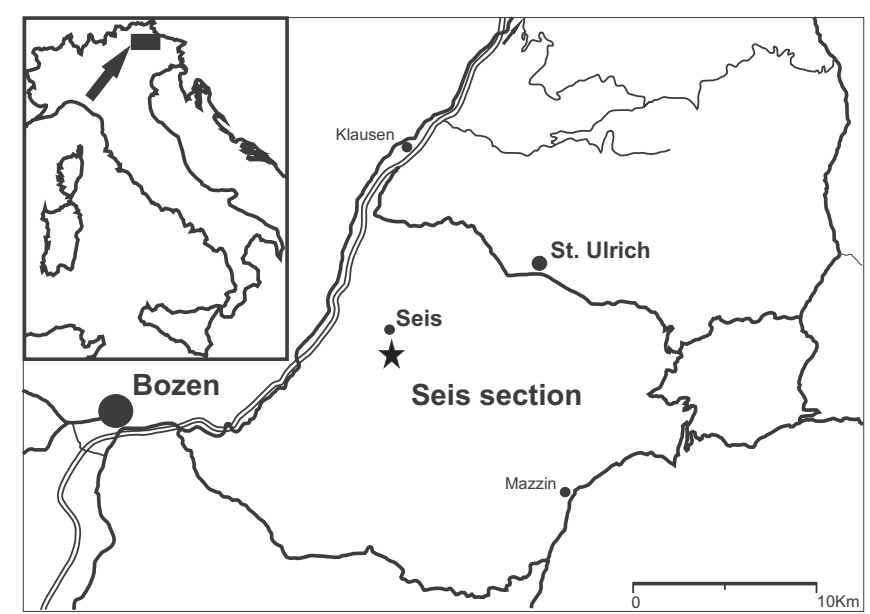

Fig. 1. Location of Seis section. 


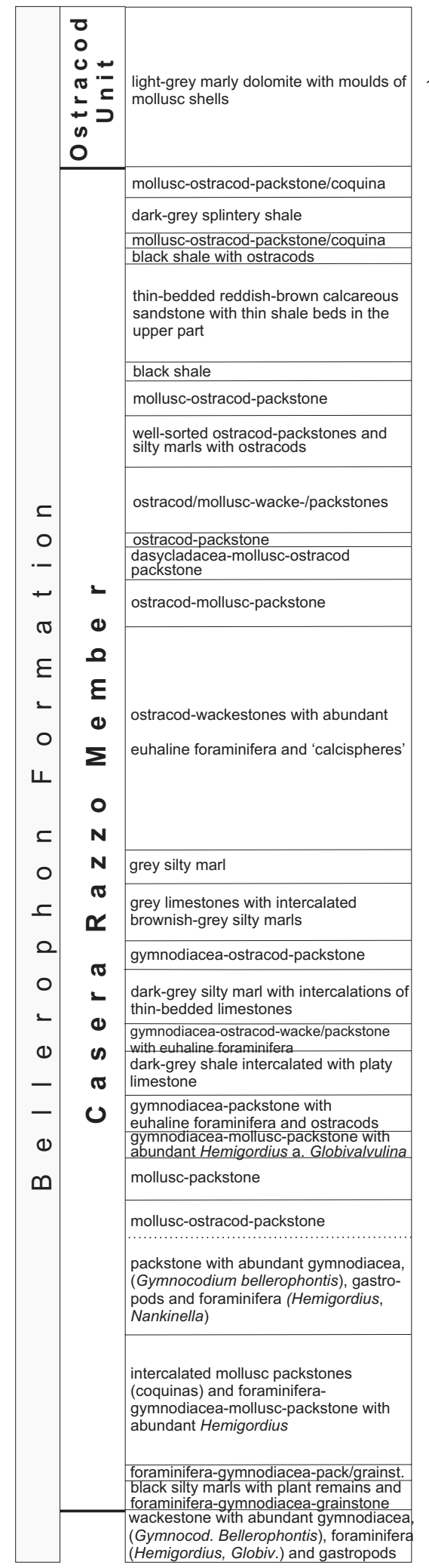

\section{0}
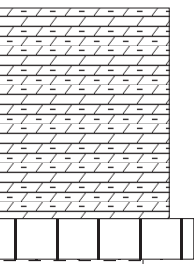

9

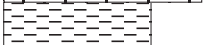

mollusc-ostracod-packstone/coquina

black shale with ostracods

hin-bedded reddish-brown calcareous upper part

8

$=-=-=--=-2$

mollusc-ostracod-packstone

well-sorted ostracod-packstones and

1

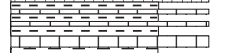

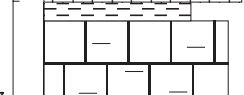

7

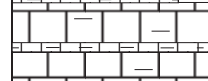

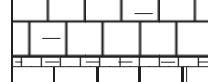
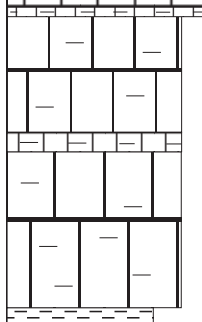

So 11

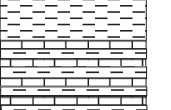

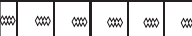

(1)

(1)

(1)

事 1

(1)

$3-10$

न1

1

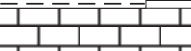

I

2

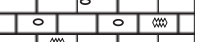

T1

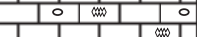

$1 \circ 1010$

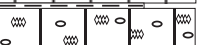

$1-$

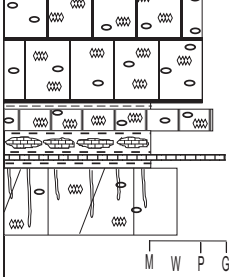

-So 8

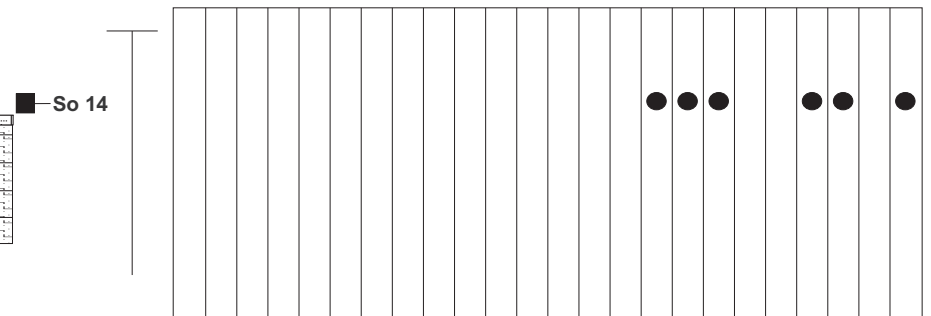

10

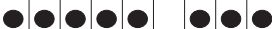

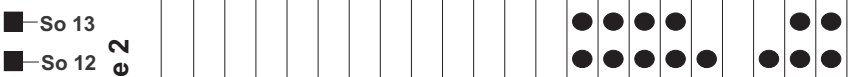

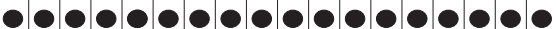

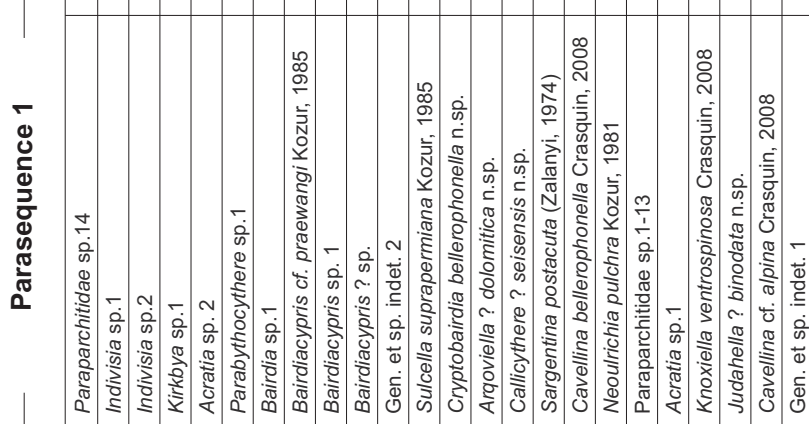

Legend:

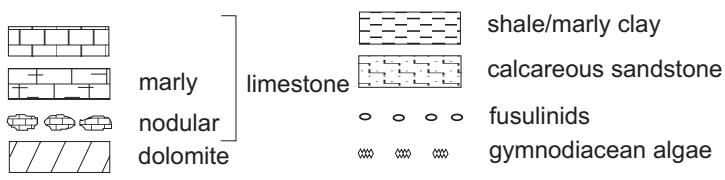

Fig. 2. Stratigraphy, facies and ostracods of the upper Bellerophon Formation (Casera Razzo Member) at Seis section. 
Both units start with thick-bedded to massive packstones and wackestones rich in euryhaline and euhaline foraminifera (Hemigordius, Nankinella, Globivalvulina amongst others) and calcareous algae (Gymnocodium bellerophontis, dasycladacean algae). In the upper part of the parasequences the shallow-marine carbonates with euhaline foraminifera are followed upsection by packstones and coquinas of monotypic fossil assemblages (molluscs, ostracods, gymnodiacean algae) intercalated with dark-grey and black shales and marls, indicative of restricted conditions. The shales contain abundant microconchids (Microconchus) which are known as eurytopic organisms (Vinn, 2010). Abundant fragments of coalified wood and other plant remains in the upper parts of parasequences 1 and 2 suggest freshwater influx and periods of hypohaline conditions which are also indicated by the disappearance of euhaline foraminifera. Increased input of terrestrial organic matter in the upper parts of parasequences 1 and 2 is also reflected by a ${ }^{13} \mathrm{C}$-enriched organic carbon isotope signature because Permian wood shows higher carbon isotope values than coeval marine organic matter (Siegert et al., 2011). It is, therefore, supposed that the benthic communities were strongly controlled by salinity variations. Environmental perturbations due to oxygen defiency seem unlikely because lamination or framboidal pyrite does not occur. Most of the ostracods described herein were recovered from the shales (samples $8,12,13,14$ ) in the upper parts of parasequences 1 and 2 . The ostracods of sample 11 are from a marly limestone horizon intercalated in thick-bedded fossiliferous wackestones of the lower parasequence 2. This assemblage consists almost exclusively of Paraparchitidae, representing at least 13 species which are documented on Plate 1. These species are not described here and left under open nomenclature due to strong recrystallization and deformation of the carapaces and valves. The palaeoenvironments and palaeoecology of the ostracod assemblages from different sections of the upper Bellerophon Formation are currently being studied. Preliminary results of this analysis are presented below.

\section{PALAEOECOLOGICAL AND \\ PALAEOBIOGEOGRAPHICAL ASPECTS \\ General remarks on ostracod taphonomy}

Autochthonous and allochthonous ostracod assemblages can be differentiated by means of population age structure analysis (Whatley, 1983a, b; 1988; Boomer et al., 2003). The latter authors pointed out that autochthonous low- to moderate-energy assemblages are characterized by the presence of adults and abundant instars of at least four moult stages, while allochthonous highenergy assemblages include only adult specimens and the largest instars. This method is, however, only practicable with well-preserved material because the valves and carapaces of juveniles are usually more easily destroyed during burial and diagenesis than the thicker-shelled adults specimens.

An additional tool for the differentiation of autochthonous and allochthonous ostracod assemblages, which can also be used for poorly preserved material, is the valve/carapace ratio (v/c ratio). The v/c ratio of fossil ostracod assemblages is controlled by the intensity and duration of various pre- and post-burial processes. The most important factors include pre-burial bacterial decomposition of organic matter, activity of scavengers and mechanical disarticulation during transport. But post-burial processes, such as bioturbation, post-burial bacterial activity and early diagenetic lithification, may also play an important role in disarticulation. The significance of these post-burial disarticulation processes has, however, not yet been studied. Kilenyi (1971a, b) reported that different ostracod taxa of Recent assemblages show very different resistance to disarticulation processes. Whatley (1988) pointed out that these differences are probably due to different strengths of hinge structures, overlap and even different physiological postmortem processes (relaxation or contraction of the adductor muscle). As noted by Boomer et al. (2003), the mode of life (infaunal, epifaunal) may also considerably control the ostracod disarticulation rate of fossil ostracod assemblages. It is, therefore, recommended to compare only $\mathrm{v} / \mathrm{c}$ ratios of single species or closely related taxa with a similar mode of life.

It is generally suggested that pre-burial biotic and abiotic processes are most important for the ostracod disarticulation and that the relative abundance of valves and carapaces in ostracod assemblages is controlled primarily by burial rate and water turbulence. A positive correlation between sedimentary rate and abundance of carapaces has been outlined by Oertli (1971). The v/c ratio may, therefore, yield important information about depositional conditions. Boomer et al. (2003) pointed out that low-energy autochthonous ostracod assemblages ('low-energy thanatocoenosis') are usually characterized by a relative high abundance of carapaces, while high-energy allochthonous assemblages ('high-energy taphocoenosis') show generally a predominance of valves. Detailed quantitative data of the range of $\mathrm{v} / \mathrm{c}$ ratios in different depositional environments are, however, not available in the literature.

\section{Taphonomy of the ostracods from Seis}

The present ostracod assemblages have not been analysed with respect to their population age structure because of fragmentation and dissolution, particularly in samples 8 and 14. The assemblages of samples 8, 12 and 13 (Fig. 3) are, however, suggested to be more or less autochthonous because they include a significant proportion of smaller instars. Furthermore, the species of these assemblages show a relatively high percentage of carapaces (average $\mathrm{v} / \mathrm{c}$ : 0.46 to 1.16). The v/c ratio of Cavellina bellerophonella Crasquin, 2008 ranges between 0.65 (sample 12) and 1.02 (sample 13). Callicythere? seisensis n. sp. and Arqoviella? dolomitica n. sp. are almost exclusively represented by carapaces. Assemblages 8 and 12 include abundant shells of encrusting organisms (microconchids) which may reflect a relatively low sedimentation rate. In contrast to assemblages 8,12 and 13 the ostracods of sample 14 are almost exclusively represented by single valves (v/c of Cavellina bellerophonella Crasquin, 2008: 33.3) which suggests that this assemblage has been post-mortally transported. Most of the shells (more than 90\%) are broken, which points to high water turbulence, probably due to a storm event. Such a storm event is recorded in the overlying mollusc/ostracod coquina (Fig. 2). Assemblage 14 shows no indications of a low burial rate, such as encrustation, bioerosion or reworking. Since the taxonomic composition of assemblage 14 is almost identical to assemblages 12 and 13 and the relative abundance is also similar, there was probably no transport over long distances and mixing of taxa from different environments. Long-distance transport would probably have separated the species due to different hydrodynamic properties of their valves. The present composition of the ostracod assemblages is thus regarded as indicative of the palaeoenvironmental conditions. A time-averaging of ostracod populations cannot be excluded, 


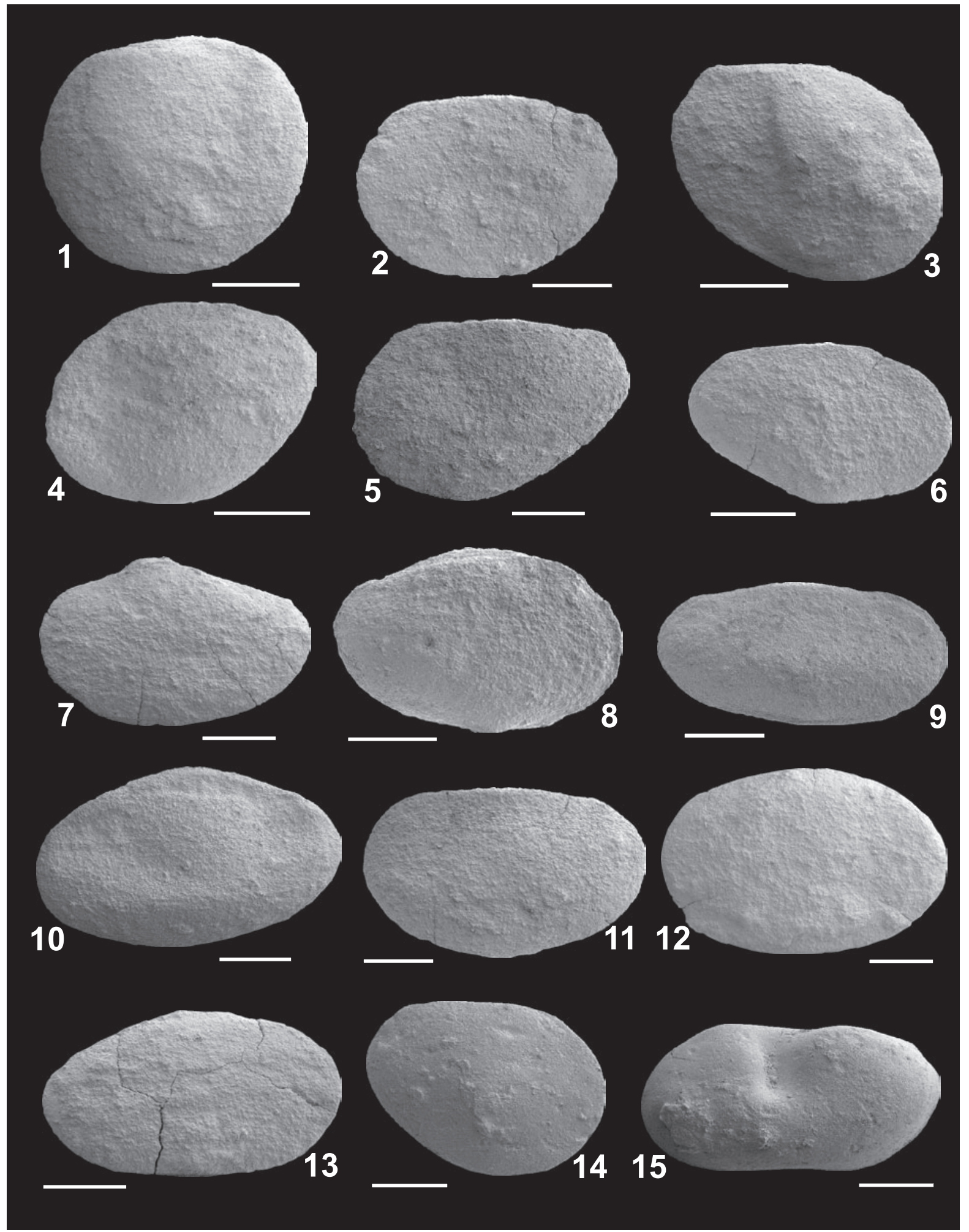

Explanation of Plate 1.

figs 1-14. Paraparchitidae gen. et sp. indet. (sp. 1-13: sample 11): 1, sp. 1, carapace, lateral view, S11-1, 6; 2, sp. 2, left valve, S11-2, 4; 3, sp. 3, carapace, right lateral view, S11-3, 15; 4, sp. 4, carapace, left lateral view, S11-2, 9; 5, sp. 5, carapace, left lateral view, S11-2, 11; 6, sp. 6, right valve, S11-2, 7; 7, sp. 7, left valve, S11-3, 9; 8. sp. 8, carapace, right lateral view, S11-1, 1; 9, sp. 9, carapace, right lateral view, S11-2, 9; 10, sp. 10, carapace, left lateral view, S11-4, 10; 11, sp. 11, left valve, S11-1, 12; 12, sp. 12, carapace, left lateral view, S11-4, 2; 13, sp. 13, right valve, S11-3, 12; 14, sp. 14, right valve, sample 8, S8-23. fig. 15. Sargentina postacuta (Zalànyi, 1974), left valve, sample 12, S12/11-4, 45. Scale bar: figs 1-13, $400 \mu \mathrm{m}$; figs $14,15,200 \mu \mathrm{m}$. 

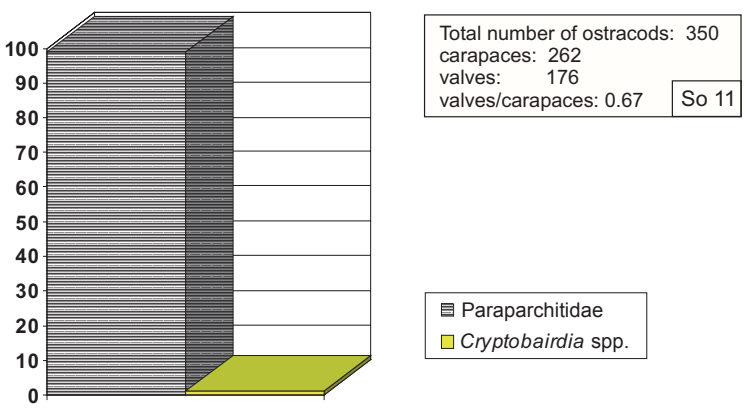

目 Paraparchitidae

$\square$ Cryptobairdia spp.

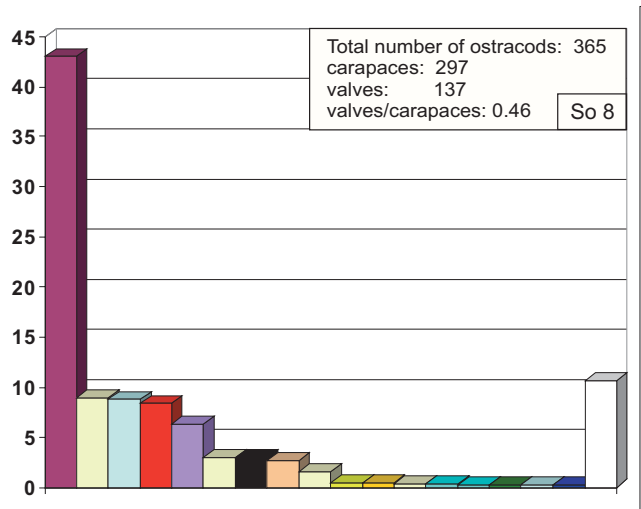

Callicythere? seisensis n. sp. $\square$ Cryptobairdia bellerophonella $\square$ Cavellina bellerophonella $\square$ Arqoviella? dolomitica $\square$ Sargentina postacuta $\square$ Bairdia spp.

- Paraparchitidae sp. indet. $\square$ Cypridadea sp. indet. $\square$ Bairdiacypris spp. $\square$ Gen. et sp. indet 2 $\square$ Bairdia sp. 1 $\square$ Acratia spp. $\square$ Indivisia sp. 2 $\square$ Indivisia sp. 1 $\square$ Parabythocythere sp. 1 $\square$ Sulcella suprapermiana Hollinella sp.

$\square$ Gen. et sp. indet.

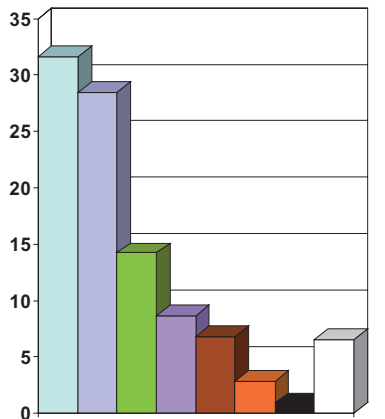

Total number of ostracods: 162 carapaces: 9

valves: 306

valves/carapaces: $34 \quad$ So 14

$\square$ Cavellina bellerophonella

$\square$ Knoxiella ventrospinosa

$\square$ Gen. et sp. indet. 1

$\square$ Sargentina postacuta

- Neoulrichia pulchra

$\square$ Judahella? binodata

- Paraparchites sp.

$\square$ Gen. et sp. indet.

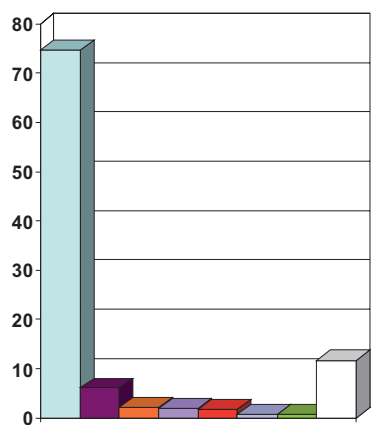

Total number of ostracods: 180 carapaces: 114

valves/carapaces: 1.16 So 13

$\square$ Cavellina bellerophonella

- Callicythere? seisensis

$\square$ Judahella? binodata

$\square$ Sargentina postacuta

$\square$ Arqoviella? dolomitica

$\square$ Knoxiella ventrospinosa

$\square$ Gen. et sp. indet. 1

$\square$ Gen. et sp. indet.

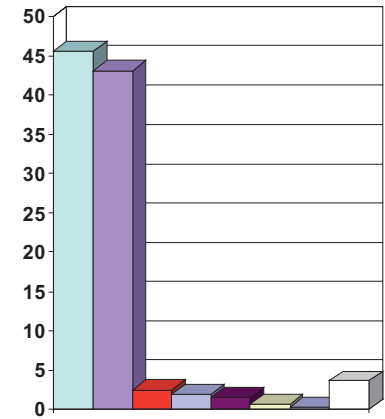

Fig. 3. Relative abundance (\%) of species in the ostracod assemblages (valves are counted as 0.5 specimen; species which represent less than $0.2 \%$ are not listed).

however, which means that the composition of the assemblages may reflect average palaeoecological conditions of a longer period.

\section{Palaeoenvironment and palaeobiogeography}

Although the lithofacies characteristics of the Casera Razzo Member at Seis section described above suggest a restricted palaeoenvironment with freshwater influx and, hence, salinity fluctuations in the upper part of the two parasequences, the ostracod taxa extracted from these intervals do not include taxa which are clearly indicative of strong brackish to freshwater conditions, such as Darwinula or Carbonita. Preliminary results of a quantitative analysis (Fig. 3) suggest that only minor salinity fluctuations occurred. The assemblage of sample 8 shows a relatively high species diversity (18 species) and a significant percentage of Bairdioidea, which may be interpreted, therefore, as a normal marine fauna. The strong dominance of Callicythere? seisensis n. sp. indicates, however, that the environment was not constantly normal marine but periods of unfavourable conditions occurred. Compared to sample 8 the assemblages of samples 12,13 and 14 show a relatively low species diversity (6-8 species) and are dominated by one or two species (Cavellina bellerophonella Crasquin, 2008, Sargentina postacuta (Zalanyi, 1974), Knoxiella ventrospinosa Crasquin, 2008, Callicythere? seisensis n. sp.), which may reflect a greater environmental instability. This interpretation is corroborated by the occurrence of $C$. bellerophonella, $S$. postacuta, $K$. ventrospinosa and C.? seisensis in the overlying 'Ostracod unit' (Crasquin et al., 2008), which was certainly deposited in a marginal marine (peritidal) environment, characterized by dolomitic mud-/wackestones with mudcracks and root traces. Crasquin et al. (2008) concluded from the high dominance of $C$. bellerophonella and $S$. postacuta that these species were eurytopic taxa with a greater tolerance to adverse environmental conditions (salinity variations, oxygen deficiency). Since the lithofacies characteristics of the Casera Razzo Member are not indicative of periods with anoxic conditions it seems, therefore, most likely that the ecological stress was actually due to salinity fluctuations. This interpretation is also supported by the fact that several Kloedenelloid genera, such as Cavellina and Knoxiella, include species which were particularly abundant in marginalmarine palaeoenvironments of the Late Palaeozoic and are thus 
interpreted as marine euryhaline taxa (Williams et al., 2006; Bennett, 2008). The ostracod assemblages of the Casera Razzo Member differ significantly from the assemblages of the overlying Bulla Member (Crasquin et al., 2008). The latter unit shows a much higher taxonomic diversity due to the transgressive character of this unit which is also reflected by the high diversity of foraminifera, brachiopods and algae (Farabegoli et al., 2007).

The ostracod assemblage of sample 11 is totally different from the other assemblages because it consists almost exclusively (more than 95\%) of different species of the Paraparchitidae (Fig. 3). The species are relatively large, thick-shelled, without spines and mostly $(60 \%)$ preserved as carapaces $(\mathrm{Pl} .1)$. The rest of the fauna is represented by poorly preserved specimens of Cryptobairdia bellerophonella $\mathrm{n}$. sp. The palaeoecology of the Paraparchitidae has been extensively studied in the Late Devonian and Carboniferous of Belgium and surrounding areas (Bless, 1983; Bless et al., 1987; Becker \& Bless, 1990). According to their results the Paraparchitidae include many euryhaline taxa and their environmental distribution was largely controlled by physical factors. Large Paraparchitidae without spines are the most common ostracods in the eulitoral zone. Considering the presence of only a few Bairdioidea in the present material it seems most likely that the assemblage of sample 11 was deposited in a nearshore environment which was transitional between the turbulent eulitoral and the shallow sublitoral zone. Smaller instars are very rare which points to a relatively high water turbulence and post-mortem transportation of the smaller specimens. Since the assemblage includes a high percentage of carapaces an autochthonous deposition in combination with rapid burial seems probable and it may thus be interpreted as a 'high-energy thanatocoenosis' (sensu Boomer et al., 2003).

The 24 species recorded from the Casera Razzo Member include only four species (or 17\%) which are also known from, or related to species of other localities outside of the Dolomites. These are: Bairdicypris cf. praewangi Kozur, 1985; Sulcella suprapermiana Kozur, 1985; Sargentina postacuta (Zalanyi, 1974) and Neoulrichia pulchra Kozur, 1981. These four species reflect palaeobiogeographical links to the Late Permian of Hungary (Bükk Mountains) (Kozur, 1985a, b). But only one of the present species (Sulcella suprapermiana Kozur, 1985) is recorded from the Upper Permian of Serbia (Crasquin et al., 2010b). The 'endemic' faunal character can be explained by the instability of environmental conditions in the Casera Razzo Member, which inhibited the immigration of faunal elements from the open-marine areas of the Tethys. This conclusion is supported by the much higher percentage $(33 \%)$ of immigrant species in the assembages of the transgressive Bulla Member (Crasquin et al., 2008).

\section{MATERIAL}

The holotypes and paratypes are housed at the Institute of Geology and Palaeontology at Innsbruck University under the number Me 2010.

\section{SYSTEMATIC DESCRIPTIONS}

The following abbreviations are used: L, length; H, height; W, width. 'Dimensions' include the maximum and minimum values of length, height and width of the present specimens.
Class Ostracoda Latreille, 1802

Order Palaeocopida Henningsmoen, 1953

Superfamily Kirkbyoidea Ulrich \& Bassler, 1906

Family Kirkbyidae Ulrich \& Bassler, 1906

Genus Kirkbya Jones, 1859

Kirkbya sp. 1

(Pl. 2, fig. 4)

?2008 Kirkbya cf. buekkensis Kozur, 1985: Crasquin et al., pl. 1, fig. 18.

Material. 2 carapaces.

Stratigraphic and geographical range. Upper Bellerophon Fm., Casera Razzo Member (sample 8), late Changsingian, Seis (Siusi) section, South Tyrol, Italy. ?Upper Bellerophon Formation, Bulla Member, late Changsingian, Pufels (Bulla) section, South Tyrol, Italy (Crasquin et al., 2008).

Remarks. The specimens probably represent a new species but it is left in open nomenclature because of insufficient material. In lateral view the species shows an elongate subrectangular carapace outline with a straight ventral margin. The posterior part of the dorsal margin is slightly inclined towards the posterior end. In dorsal view the carapace is very weakly convex and not inflated laterally. Parallel to the anterior, ventral and posterior margin run two narrow and shallow ribs. These marginal ribs converge at the anterior and posterior cardinal angles into a narrow and shallow dorsal rib. The lateral surface shows an irregular reticulation and, in the central part, very weakly developed longitudinal ribs which are slightly inclined towards the anterior margin. The kirkbyan pit is small and shallow.

The present material may belong to the same species as Kirkbya cf. buekkensis Kozur, 1985 in Crasquin et al. (2008). The latter species was, however, not described in the text and documented by only one incomplete carapace. Kirkbya sp. 1 differs from the other species of Kirkbya in the type of ornamentation, very narrow and low marginal ribs and narrow carapace outline in dorsal view.

Order Podocopida Müller, 1894

Suborder Platycopina Sars, 1866

Superfamily Kloedenelloidea Ulrich \& Basler, 1908

Family Cavellinidae Egorov, 1950

Genus Cavellina Coryell, 1928

Cavellina bellerophonella Crasquin, 2008

(P1. 2, figs 6-10)

2008 Cavellina bellerophonella Crasquin n. sp.: Crasquin et al., 2008, p. 254, pl. 6, figs 3-7.

Material. More than 233 carapaces and 279 valves.

Stratigraphic and geographical range. Upper Bellerophon Formation, 'Ostracod unit', late Changsingian, Pufels (Bulla) section, South Tyrol, Italy (Crasquin et al., 2008). Upper Bellerophon Formation, Casera Razzo Member (samples 8, 12, 13, 14), late Changsingian, Seis (Siusi) section, South Tyrol, Italy. 


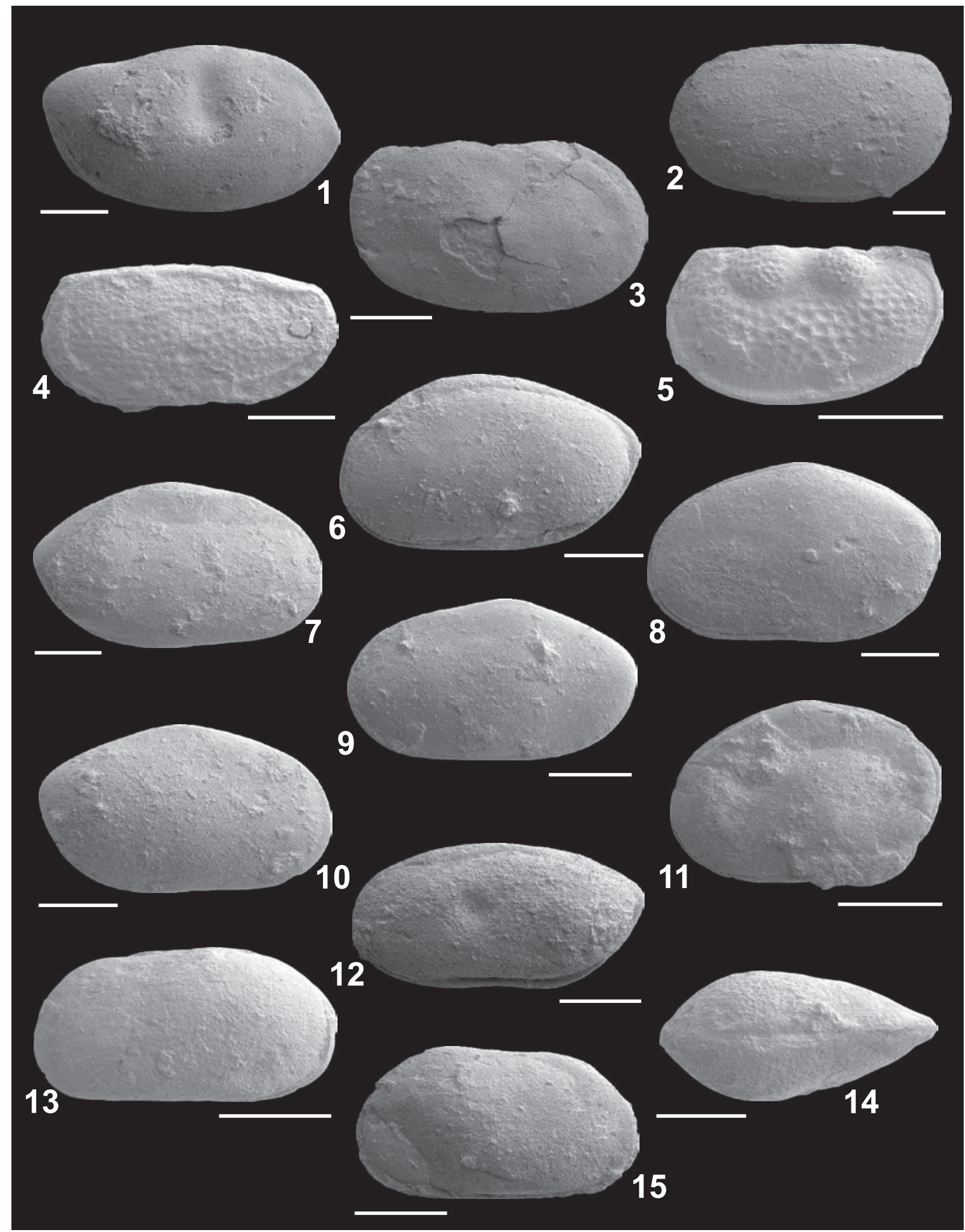

Explanation of Plate 2.

fig. 1. Sargentina postacuta (Zalànyi, 1974), right valve, sample 12, S12/11-4, 46. fig. 2. Indivisia sp. 1, carapace, left lateral view, sample 8, S8-35. fig. 3. Indivisia sp. 2, right valve, sample 8, S8-37. fig. 4. Kirkbya sp. 1, carapace, left lateral view, sample 8, S8-34. fig. 5. Neoulrichia pulchra Kozur, 1981, left valve, sample 14, S14/11-5, 22. figs 6-10. Cavellina bellerophonella Crasquin, 2008: 6, female carapace, left lateral view, sample12, S12/11-4, 16; 7, female right valve, sample 12 , S12/11-4, 17; 8, male carapace, left lateral view, sample 13 , S13/11-4, 20; 9, male left valve, sample 12, S12/11-4, 13; 10, female right valve, sample 12, S12/11-4, 14. fig. 11. Cavellina cf. alpina, Crasquin, 2008, carapace, left lateral view, sample 13, S13/11-5, 6. fig. 12. Sulcella suprapermiana Kozur, 1985, male carapace, left lateral view, sample 8, S8-14. figs 13-15. Callicythere? seisensis $\mathrm{n}$. sp.: 13, holotype, female carapace, left lateral view, sample 13, S13/11-5, 26; 14, female carapace, dorsal view, sample 13, S13/11-5, 25; 15, female carapace, right lateral view, sample 8, S8/11-5, 29. Scale bar $200 \mu \mathrm{m}$. 
Remarks. The female specimens differ from the males in the posterior swelling of the carapace and in the shape of the dorsal border. Both valves of the male carapaces show an angulation of the dorsal border at or just behind mid-length. In the females the dorsal border of the left valve is evenly convex or gently angled at mid-length and the right valve does not show an angulation at the dorsal border. The posterior margin is angled at or just above midheight; this angulation is particuarly distinct in the right valve.

The present specimens show a higher maximum carapace size $(0.94 \mathrm{~mm})$ and a slightly higher maximum height/length ratio (0.64) than those specimens of Cavellina bellerophonella which were recorded from the 'Ostracod unit' of the Pufels section (Crasquin-Soleau et al., 2008). These minor differences are regarded as intraspecific variabilty. C. bellerophonella is suggested to be a descendant of Cavellina visnoyensis Kozur, 1985 from the Middle Permian of Hungary (Kozur, 1985a) which differs in the higher length/height ratio and occurrence of a shallow subdorsal carapace depression on the left valve.

Family Indivisidae Egorov, 1954

Genus Indivisia Zaspelova, 1953

Indivisia $\mathrm{sp.} 1$

(P1. 2, fig. 2)

Material. 1 carapace.

Stratigraphic and geographical range. Upper Bellerophon Formation, Casera Razzo Member (sample 8), late Changsingian, Seis (Siusi) section, South Tyrol, Italy.

Remarks. A characteristic feature of the present specimen is the subovate outline of the carapace in lateral view with an obtuse posterior cardinal angle and a rounded anterodorsal margin. The anterior margin is symmetrical and more narrowly rounded than the posterior margin which is slightly flattened in the posteroventral part. The ventral margin is slightly convex and the maximum height is located in the posterior portion of the carapace, just behind the middle. There is no median sulcus and no ornamentation on the lateral surface. With regard to the carapace shape Indivisia sp. 1 is comparable to Indivisia symmetrica Kozur, 1985 but can be distinguished from that species by the much greater carapace size and the asymmetrically rounded posterior margin. Indivisia $\mathrm{cf}$. symmetrica Kozur in Crasquin et al. (2010b) is also much smaller and shows a flattened posterior and asymmetrical anterior margin. Compared to Indivisia pelikani Kozur, 1985 the present specimen differs clearly in the subovate lateral outline, particularly the different shape of the anterior and posterior margins. The species which was documenated as 'Indivisia symmetrica Kozur, 1985' in Crasquin et al. (2010a) is more similar to the present specimen but also of much smaller size. Another comparable species is the Lower Permian Indivisia nuzhencevi Kotchetkova, 1972 (in Kotchetkova \& Gusseva, 1972). It is particularly similar in lateral view but, in contrast to the latter species, Indivisia sp. 1 has a more obtuse posterior cardinal angle and its dorsal margin is not incised.

Indivisia $\mathrm{sp} .2$

(Pl. 2, fig. 3)

Material. 3 valves.
Stratigraphic and geographical range. Upper Bellerophon Formation, Casera Razzo Member (sample 8), late Changsingian, Seis (Siusi) section, South Tyrol, Italy.

Remarks. This species shows a distinct posterior cardinal angle, a gently convex ventral margin with the greatest height located before the middle. The anterior margin is strongly convex and almost symmetrically rounded while the posterior margin shows a much more asymmetrical convexity. It is most similar to Indivisia pelikani Kozur, 1985 from which Indivisia sp. 2 can be distinguished by the gently convex ventral margin. Another important difference is the oblique posterior margin of I. pelikani Kozur, 1985.

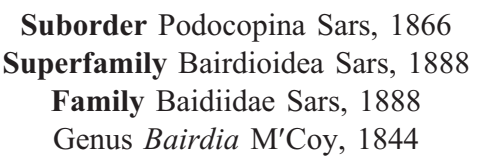

\section{Bairdia sp. 1}

(P1. 4, figs 4-5)

Material. 4 left valves, 1 right valve.

Stratigraphic and geographical range. Upper Bellerophon Formation, Casera Razzo Member (sample 8), late Changsingian, Seis (Siusi) section, South Tyrol, Italy.

Remarks. Bairdia sp. 1 is characterized by a distinct angulation of the left dorsal margin and its bipartition into a gently inclined anterior part and a more strongly inclined posterior part. The left posterior margin is very narrowly rounded. In lateral outline the present species is reminiscent of Truncobairdia beaglensis Jones, 1970 from the Lower Triassic of Western Australia but the present species lacks the truncation of the posterior end and the right valve is different in lateral outline. Bairdia sp. 1 differs from the other species of Bairdia in the conspicuous lateral outline of the left valve and is, therefore, regarded as a new species. It is left in open nomenclature due to insufficient material.

Genus Cryptobairdia Sohn, 1960

Cryptobairdia bellerophonella $\mathrm{n}$. $\mathrm{sp}$. (P1. 4, figs 6-9)

Derivation of name. From its occurrence in the Bellerophon Formation.

Diagnosis. A species of Cryptobairdia with an angulation of the left anterior margin just below mid-height and a left posterior margin which is weakly angled at two-fifths of carapace height. The smaller right valve shows almost symmetrically rounded anterior and posterior margins.

Holotype. S8-8; carapace, Plate 4, fig. 9.

Material. 5 carapaces and 5 valves of adult specimens; 15 carapaces and 21 valves of juvenile specimens.

Type locality and horizon. Seiser Klamm (Gola di Siusi), $1 \mathrm{~km}$ south of the village Seis, South Tyrol (Dolomites), Italy; dark-grey 


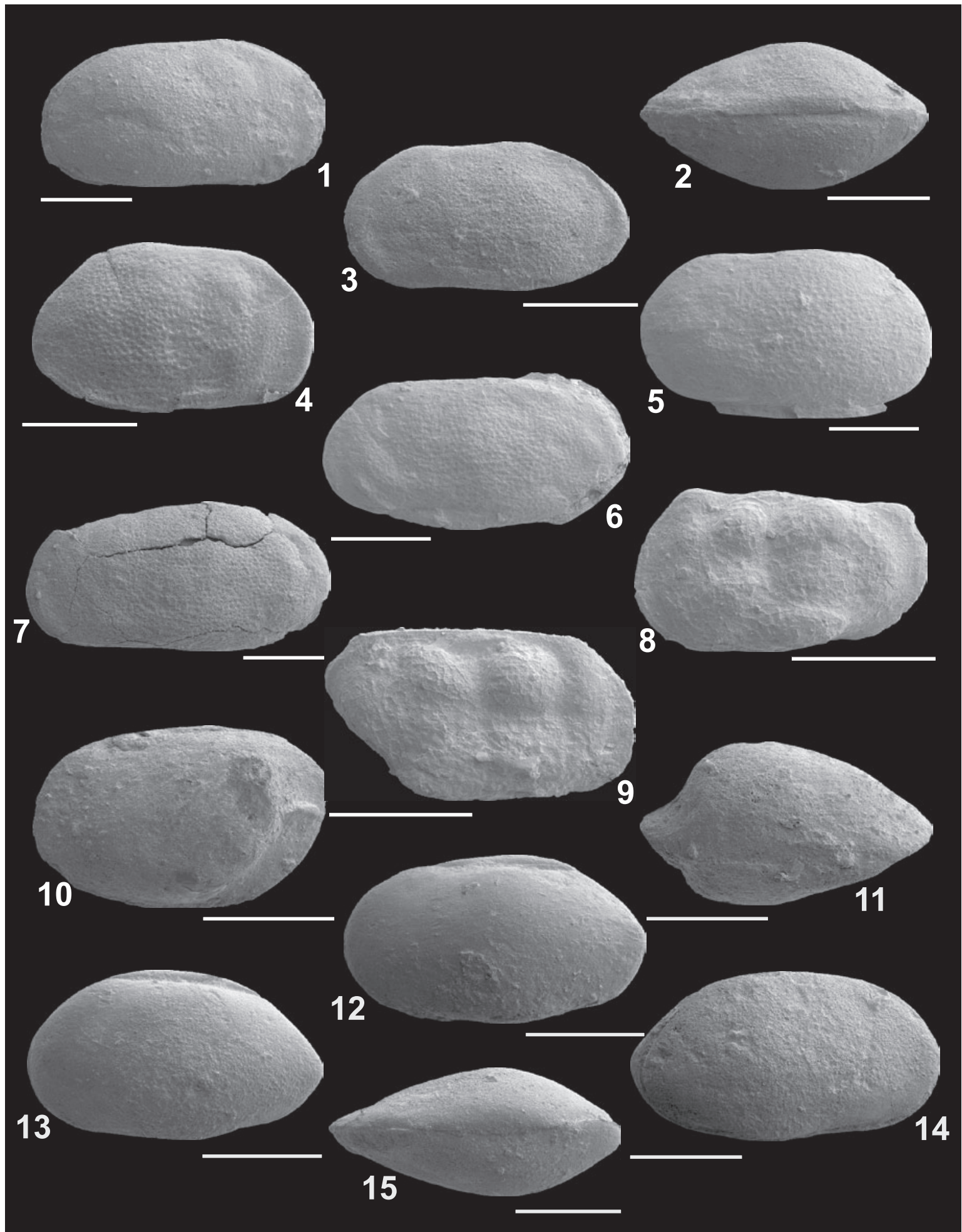

Explanation of Plate 3 .

figs 1-2. Callicythere? seisensis n. sp., sample 8: 1, male carapace, right lateral view, S8/11-5, 27; 2, male carapace, dorsal view, S8/11-5, 30. figs 3-7. Gen. et sp. indet. 1, sample 14: 3, female?, left valve, S14/11-4, 28; 4, female?, right valve, S14/11-4, 29; 5, female?, left valve, S14/11-4, 31; 6, male?, right valve, S14/11-4, 32; 7, male?, left valve, S14/11-4, 36. figs 8-9. Judahella? binodata $\mathrm{n}$. sp.: 8, holotype, left valve, sample 13, S13/11-4, 42; 9, right valve, sample 14, S14/11-4, 40. figs 10-11. Parabythocythere sp. 1: 10, carapace, left lateral view, sample 8, S8-39; 11, carapace, dorsal view, sample 8, S8-39. figs 12-15 Arqoviella? dolomitica n. sp.: 12, male carapace, left lateral view, sample 12, S12/11-4, 23; 13, holotype, male carapace, left lateral view, sample $8, \mathrm{~S} 8 / 11-5,32 ; \mathbf{1 4}$, male carapace, right lateral view, sample 12, S12/11-4, 22; 15, male carapace, dorsal view, sample 8, S8-1. Scale bar $200 \mu \mathrm{m}$. 


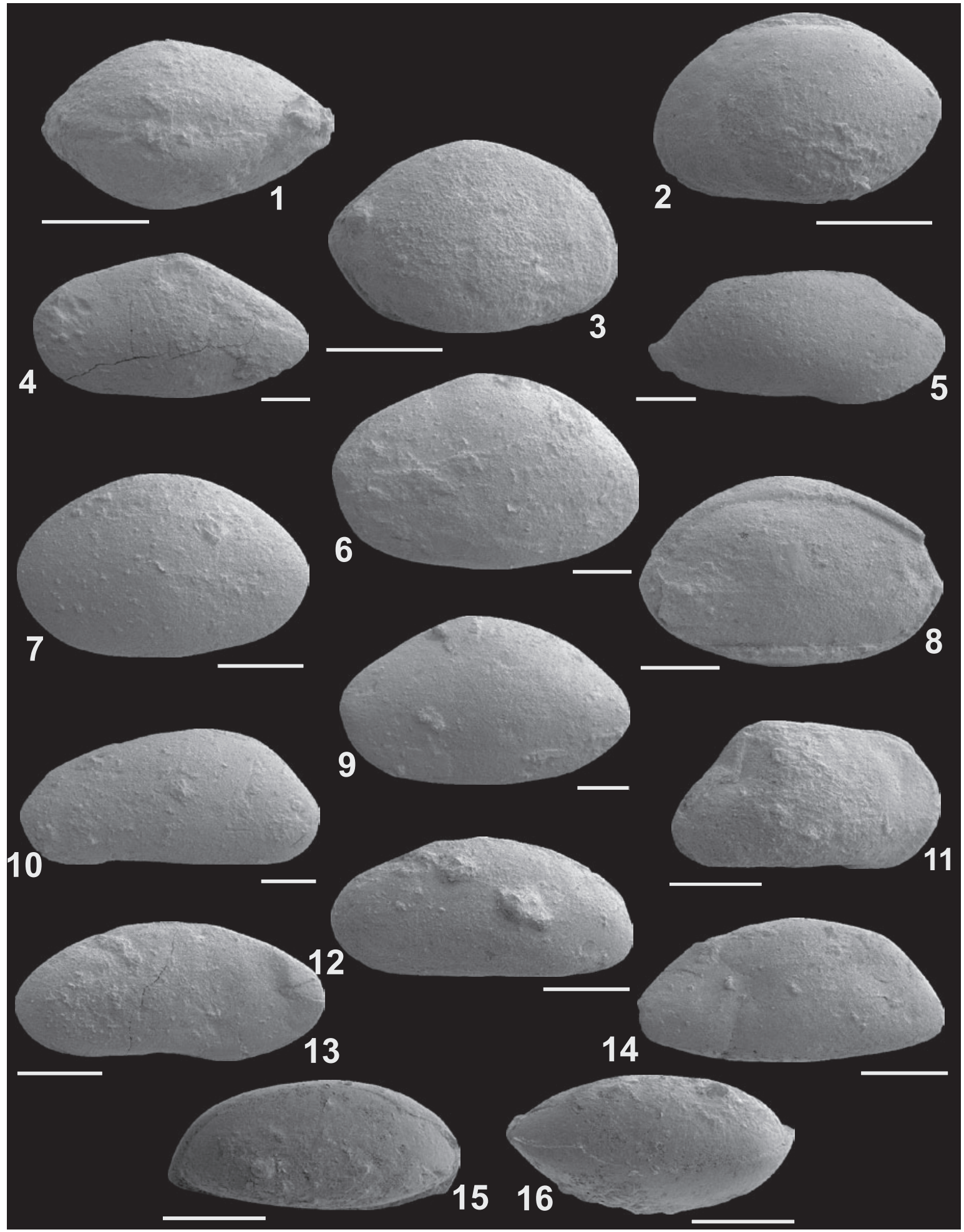

Explanation of Plate 4.

figs 1-3. Arqoviella? dolomitica n. sp.: 1, female carapace, dorsal view, sample 8, S8-3; 2, female carapace, left lateral view, sample 8, S8-4; 3, female carapace, right lateral view, sample 8, S8-5. figs 4-5. Bairdia sp. 1, sample 8: 4, left valve, S8-11; 5, right valve, S8-12. figs 6-9. Cryptobairdia bellerophonella $\mathrm{n}$. sp., sample 8: 6, left valve, S8-10; 7, juvenile carapace, left lateral view, S8-6; 8, juvenile carapace, right lateral view, S8-9; 9 , holotype, carapace, left lateral view, S8-8. fig. 10. Bairdiacypris cf. praewangi Kozur, 1985, left valve, sample 8, S8-13. fig. 11. Gen. et sp. indet. 2, carapace, right lateral view, sample 8, S8-28. fig. 12. Bairdiacypris sp. 1, carapace, left lateral view, sample 8, S8-21. fig. 13. Bairdiacypris? sp., right valve, sample 8, S8-26. fig. 14. Acratia sp. 2, left valve, sample 8, S8-19. figs 15-16. Acratia sp. 1, sample 12, S12/11-5, 1: 15, carapace, right lateral view; 16, carapace, dorsal view. Scale bar $200 \mu \mathrm{m}$. 
silty shale (sample 8 ), $0.8 \mathrm{~m}$ below a $2.7 \mathrm{~m}$ thick unit of thickbedded to massive micritic limestone, upper Bellerophon Formation, Casera Razzo Member.

Age. Late Changsingian.

Description. In lateral view the carapace displays a moderately convex dorsal margin with a more or less flattened anterodorsal part on the left valve. The anterior margin of the left valve is more or less distinctly angled just below mid-height and gradually merges into the straight or gently convex ventral margin. Some juvenile specimens show a symmetrically rounded left anterior margin without any angulation. The posterior margin of the left valve is narrowly rounded or angled at two-fifths of carapace height with a gently convex posterodorsal part. Anterior and posterior margins of the right valve are narrowly rounded and almost symmetrical to each other. The dorsal margin of the right valve consists of a straight median part which is slightly inclined towards the posterior end and distinctly inclined anterodorsal and posterodorsal parts. At the ventral margin of the right valve occurs a distinct median concavity. In dorsal view the carapace shows a narrow outline, with the greatest width located at or just behind mid-length and tapering anterior and posterior extremities.

Dimensions (mm). Left valve: L 1.06/H 0.62; L 1.18/H 0.69; carapace (holotype) L 1.20/H 0.70; L 1.04/H 0.62/W 0.40.

Stratigraphic and geographical range. Upper Bellerophon Formation, Casera Razzo Member (sample 8 and 11), late Changsingian, Seis (Siusi) section, South Tyrol, Italy.

Remarks. Cryptobairdia bellerophonella is comparable to Cryptobairdia maddocksi Kozur, 1985 but, in contrast to the latter species, C. bellerophonella shows a more or less distinct angulation of the anterior margin and the right valve lacks antero- and posterodorsal concavities. Another similar species is Bairdia beedei Ulrich \& Bassler, 1906 but the present material differs from $B$. beedei in the almost symmetrically rounded posterior margin of the right valve.

Family Acridiidae Gründel, 1962

Genus Acratia Delo, 1930

Acratia sp. 1

(P1. 4, figs 15-16)

?1978 Acratia zhongyingensis Wang: 295, pl. 4, figs 5-6.

?2002 Acratia zhongyingensis Wang: Shi \& Chen, pp. 82-83, pl. 20, figs 25-26.

2008 'Acratia zhongyingensis Wang 1978': Crasquin et al., p. 250 , pl. 5 , figs $10-12$.

Material. 1 carapace.

Stratigraphic and geographical range. Upper Bellerophon Formation, Casera Razzo Member (sample 12), late Changsingian, Seis (Siusi) section, South Tyrol, Italy. Upper Bellerophon Formation, 'Ostracod unit', lower Tesero Member ('Tesero Oolite'), late Changsingian, Pufels (Bulla) section, South Tyrol, Italy (Crasquin et al., 2008). ?Late Permian of Western Guizhou
Province (Wang, 1978) and Zhejiang Province (Shi \& Chen, 2002), China.

Remarks. The species is characterized by a gently convex dorsal margin, strongly convex antero- and posterodorsal margins, a sharply pointed posterior end and a narrowly rounded anterior margin. The ventral margin is slightly upturned anteriorly. In dorsal view the carapace displays a symmetrically convex outline with the greatest width located at mid-length. The overlap of the left valve over the right valve is most strong at the anterodorsal margin. The present species corresponds in carapace outline and overlap structure to the species which was recorded as 'Acratia zhongyingensis Wang, 1978' in Crasquin et al. (2008) from the Upper Permian and Lower Triassic of the Dolomites (Bulla section). According to the original documentation in Wang (1978), A. zhongyingensis has a more convex dorsal margin and a laterally compressed anterior end. It seems, therefore, questionable if the present species is conspecific with the species from China. Acratia sp. 1 corresponds to Acratia n. sp. 3 in Crasquin et al. (1999) in the lateral carapace outline but the latter species lacks the strong anterodorsal overlap of the left valve. It differs from Acratia posthungarica Kozur, 1985 in the less convex dorsal margin and the less strongly tapering anterior end.

\section{Superfamily Cytheroidea Baird, 1850 \\ Family Cytheruridae Sars, 1925 \\ Genus Judahella Sohn, 1968}

Judahella? binodata $\mathrm{n}$. sp.

(P1. 3, figs 8-9)

?1970 Judahella? sp.: Sohn, p. 202, pl. 1, figs 26, 27.

Derivation of name. Referring to the occurrence of two prominent nodes on the subdorsal part of the lateral surface.

Diagnosis. The most conspicuous feature of the present species is the occurrence of two subequal nodes in the subdorsal part of the lateral surface and an elongate and tumid ventrolateral node. The lateral surface is covered by a delicate reticulation.

Holotype. S13/11-4, 42; left valve, Plate 3, fig. 8.

Material. 2 carapaces, 15 valves.

Type locality and horizon. Seiser Klamm (Gola di Siusi), $1 \mathrm{~km}$ south of the village Seis (Siusi), South Tyrol (Dolomites), Italy; dark-grey silty shale (sample 13), $0.25 \mathrm{~m}$ above a $2.7 \mathrm{~m}$ thick unit of thick-bedded to massive micritic limestone, upper Bellerophon Formation, Casera Razzo Member.

Age. Late Changsingian.

Description. Judahella? binodata $\mathrm{n}$. sp. has a subrectangular outline in lateral view with a straight dorsal margin, which is inclined towards the posterior, a straight ventral margin, a broadly and almost symmetrically rounded anterior margin and a more narrowly rounded posterior margin. The posterior margin of the right valve is pointed above mid-height. The carapace is laterally 
compressed at the anterior and posterior marginal zones. On the lateral surface occur two prominent subdorsal nodes which are separated by a distinct subcentral sulcus extending from the dorsal margin in vertical direction below mid-height. Another short subvertical sulcus is located in the anterodorsal part of the lateral surface. It separates the anterior node from a more or less distinct anterodorsal lobe extending from the anterior cardinal angle to mid-height. A third more or less distinct node is situated under the anterodorsal node, just below mid-height. In the middle part of the ventrolateral surface occurs a short and elongate node which forms a blunt wing-like extension. The lateral surface, except the compressed marginal zones, is covered by a delicate reticulate ornamentation.

Dimensions (mm): Valve: L $0.41 / \mathrm{H} 0.23$; L $0.44 / \mathrm{H} 0.24$; carapace: L $0.41 / \mathrm{H} 0.25$.

Stratigraphic and geographical range. Upper Bellerophon Formation, Casera Razzo Member (samples 12, 13, 14), late Changsingian, South Tyrol, Italy. ?Mianwali Formation, Mittiwali Member, Lower Triassic (Griesbachian), Salt Range, Pakistan (Sohn, 1970).

Remarks. The species is considered to be closely related to Judahella because of the similar shape of the carapace, ocurrence of prominent subdorsal nodes and reticulate ornamentation. There are, however, some features which suggest that the Judahella? sp. 1 may represent a closely related genus. The present specimens do not show an eye node and they bear only two subdorsal nodes. The low number of specimens, poor preservation and inaccessibility of internal features, however, preclude an exact systematic assignment. A species which shows some affinity to the present material is Judahella? sp. from the Lower Triassic (Griesbachian) of Pakistan (Sohn, 1970), but in contrast to the present species the specimen figured by Sohn lacks an anteroventral node and shows a delicate longitudinal ridge on the lateral surface.

Family Bythocytheridae Sars, 1928

Genus Parabythocythere Kozur, 1981

Parabythocythere sp. 1

(Pl. 3, figs 10-11)

Material. 1 carapace

Stratigraphic and geographical range. Upper Bellerophon Formation, Casera Razzo Member (sample 8), late Changsingian, Seis (Siusi) section, South Tyrol, Italy.

Remarks. The present specimen probably represents a new species but is left under open nomenclature because of insufficient material. It differs from the other known species of Parabythocythere in the shape of the carapace. It is squat in lateral view, strongly convex in dorsal view and shows a broadly rounded posterior margin. The maximum height is located in the posterior part at about two-fifths of carapace length. Posteriorly there is a very broad laterally compressed marginal zone. The specimen is poorly preserved and does not display any surface ornamentation.
?Family Cytheressinellidae Kashevarova, 1958

Genus Arqoviella Gerry \& Honigstein, 1987

Arqoviella? dolomitica n. sp. (Pl. 3, figs 12-15; Pl. 4, figs 1-3)

?2008 Arqoviella sp. 1: Crasquin et al., pl. 6, figs 17, 18, 19.

Derivation of name. From its occurrence in the Dolomites.

Diagnosis. A species characterized by a sharp angulation of the posterior margin, strong ventrolateral carapace inflation and reverse dorsal overlap structure: The right valve distinctly overlaps the left valve at the dorsal margin.

Holotype. S8/11-5, 32; carapace (Form A), Plate 3, fig. 13.

Material. Form A: 15 carapaces, 1 valve; Form B: 19 carapaces, 1 valve.

Type locality and horizon. Seiser Klamm (Gola di Siusi), $1 \mathrm{~km}$ south of the village Seis, South Tyrol (Dolomites), Italy; darkgrey silty shale (sample 8 ), $0.8 \mathrm{~m}$ below a $2.7 \mathrm{~m}$ thick unit of thick-bedded to massive micritic limestone, upper Bellerophon Formation, Casera Razzo Member.

Age. Late Changsingian.

Description. The present specimens have a subovate outline in lateral view and do not show any ornamentation. A characteristic feature of the species is the distinct angulation of the posterior margin of the left valve at mid-height or just below mid-height which strongly overlaps the narrowly rounded right posterior margin. Another typical feature of the species is the reverse overlap at the dorsal margin. The right valve strongly overlaps the left valve at the dorsal margin; at the anterodorsal, posterodorsal, anterior and ventral margins the left valve slightly overlaps the right valve. In dorsal view the carapace shows maximum inflation in the posterior part at two-fifths of carapace length. The species displays a moderate to strong ventrolateral carapace inflation which slightly overreaches the ventral margin. Due to this inflation the carapace outline is subtriangular in frontal view. Internal features are not accessible. The material includes relatively slender specimens (Form A) and shorter, more inflated specimens (Form B). It seems very probable that Form $\mathrm{A}$ and Form B represent male and female carapaces.

Form A (presumed male): These specimens are relatively slender in lateral carapace outline with a moderately convex dorsal margin. The anterior margin of both valves is almost symmetrically rounded and only slightly flattened anterodorsally. In dorsal view the carapace is lens-shaped and shows a moderate ventrolateral carapace inflation (Pl. 3, figs 12-15).

Form B (presumed female): These specimens have a short carapace which is strongly convex dorsally and laterally more inflated than Form A (Pl. 4, figs 1-3). In contrast to Form A the anterior margin is clearly asymmetrically rounded with a maximum of curvature at one-third of carapace height.

Dimensions (mm): Form A (male carapace?) - holotype: L 0.49/H $0.29 ;$ L $0.54 / \mathrm{H} \quad 0.34 / \mathrm{W} \quad 0.29 ;$ L $0.56 / \mathrm{H} \quad 0.33 / \mathrm{W} \quad 0.28$; L 
0.59/H 0.34/W 0.27. Form B (female carapace?): L $0.45 / \mathrm{H}$ 0.35/W $0.30 ; \mathrm{L} \quad 0.50 / \mathrm{H} \quad 0.40 / \mathrm{W} \quad 0.31 ; \mathrm{L} \quad 0.50 / \mathrm{H} \quad 0.36 / \mathrm{W} \quad 0.34 ; \mathrm{L}$ $0.54 / \mathrm{H} \quad 0.36 / \mathrm{W} 0.32$.

Stratigraphic and geographical range. Upper Bellerophon Formation, Casera Razzo Member (samples 8, 12, 13), late Changsingian, Seis (Siusi) section, South Tyrol, Italy. ?Upper Bellerophon Formation, 'Ostracod unit', Bulla Member, late Changsingian, Pufels (Bulla) section, South Tyrol, Italy (Crasquin et al., 2008).

Remarks. The exact systematic position of the present species is unknown because the hinge structure and other internal features are not accessible. With regard to carapace outline, it shows affinities to Pulviella but differs from the latter genus by the alternating overlap structure and absence of ornamentation at the ventral surface. The assignment to Arqoviella is based on similarities in the shape and overlap structure of the carapace but this interpretation is questionable because all presently known species of Arqoviella show a more or less strong reticulate ornamentation of the lateral surface. Arqoviella? sp. 1 which was recorded from the Upper Permian of the Dolomites (Crasquin et al., 2008) coincides in carapace outline with some specimens of the present species (Form B) but Arqoviella? sp. 1 was not described in the text and the figures do not allow a detailed comparison with the present material.

?Genus Callicythere Wei, 1981

Callicythere? seisensis n. sp.

(P1. 2, figs 13-15; P1. 3, figs $1-2$ )

2008 Callicythere mazurensis (Styk, 1972): Crasquin et al., p. 254, pl. 5, figs 20-21.

Derivation of name. From its occurrence near the village of Seis (Siusi).

Diagnosis. The species is characterized by a smooth carapace with subovate outline in lateral view, reverse overlap structure at the dorsal margin and greatest height located at the posterior cardinal angle at one-quarter of carapace length. The curvature of the anterior and posterior margins is clearly asymmetrical.

Holotype. S13/11-5, 26; female carapace, Plate 2, fig. 13.

Material. 167 carapaces, 12 valves.

Type locality and horizon. Seiser Klamm (Gola di Siusi), $1 \mathrm{~km}$ south of the village of Seis (Siusi), South Tyrol (Dolomites), Italy; dark-grey silty shale (sample 13), $0.25 \mathrm{~m}$ above a $2.7 \mathrm{~m}$ thick unit of thick-bedded to massive micritic limestone, upper Bellerophon Formation, Casera Razzo Member.

Age. Late Changsingian.

Description. The species has a subovate carapace outline in lateral view with broadly rounded anterior and posterior margins. The left valve overlaps the right valve slightly at the anterior, posterior and ventral margins and the right valve overlaps the left valve more clearly along the dorsal margin. The anterior and posterior margins are broadly rounded but the curvature is flattened above mid-height particularly at the posterior margin. The transition of the dorsal margin into the anterior and posterior margins is rounded. The ventrolateral parts of the carapace slightly overreach the ventral margin in lateral view and the ventral surface is slightly flattened. There is no ventrolateral carapace inflation so that the carapace outline in frontal view is almost symmetrically convex with the greatest width located at mid-height or just below mid-height. In the subdorsal area, just in front of the middle of the lateral surface, there is a shallow and broad carapace depression. In dorsal view the maximum lateral carapace width is located just behind mid-length or at one-third to two-fifths of carapace length. Some specimens show a lateral compression at the anterior marginal zone. The present specimens do not show any surface ornamentation. Internal features are not accessible because the material includes almost exclusively closed carapaces.

It seems probable that $C . ?$ seisensis shows sexual dimorphism: Most of the specimens are swollen posteriorly and are regarded as females. The maximum lateral carapace width of these specimens is located at one-third to two-fifths of carapace length and the anterior portion of the carapace is tapered towards the anterior end. In lateral view the dorsal margin is slightly inclined towards the anterior end and the maximum height occurs in the posterior part at one-quarter of carapace length. A few specimens, which probably represent the males, lack the posterior swelling and show an almost symmetrical carapace outline in dorsal view with the maximum width located at mid-length or just behind midlength. The dorsal margin of these specimens is parallel to the ventral margin.

Dimensions (mm): Female carapace - holotype: L 0.50/H 0.25; L $0.56 / \mathrm{H} \quad 0.34 ;$ L $0.58 / \mathrm{H} \quad 0.36 / \mathrm{W} \quad 0.32$; L $0.60 / \mathrm{H} \quad 0.36 / \mathrm{W}: 0.32$. Male carapace: L $0.52 / \mathrm{H} \quad 0.32 / \mathrm{W} \quad 0.29$; L $0.56 / \mathrm{H} \quad 0.31 / \mathrm{W} \quad 0.29$; L $0.60 / \mathrm{H} 0.36$.

Stratigraphic and geographical range. Upper Bellerophon Formation, Casera Razzo Member (samples 8, 12, 13), late Changsingian, Seis (Siusi) section, South Tyrol, Italy. ?Upper Bellerophon Formation, 'Ostracod unit', late Changsingian, Pufels (Bulla) section, South Tyrol, Italy (Crasquin et al., 2008).

Remarks. With regard to carapace outline and overlap structure the present species shows affinity to Callicythere. But according to the original diagnosis of Callicythere in Wei (1981) the maximum height of this genus occurs in the anterior portion of the carapace, not in the posterior portion and it is also of distinctly smaller size. The anterior margin of Callicythere is symmetrically rounded. In dorsal view the carapace of Callicythere is more strongly and symmetrically convex and not tapering towards the anterior and posterior ends. Another similar genus is Lutkevichinella. In contrast to the latter genus the maximum height of the present species is situated in the posterior part of the carapace. Furthermore, the sharp central sulcus (S1) and the anterodorsal sulcus (S2) seen in Lutkevichinella are missing. The present species is also larger than most representatives of Lutkevichinella. It seems possible that the present species represents an early precursor of Callicythere or Lutkevichinella. The exact systematic position can, however, only be determined if internal features are accessible. 
C.? seisensis can be distinguished from the Middle Triassic species Lutkevichinella minima Starozhilova, 1968 by its greater carapace size and absence of ornamentation. The lower Triassic species Lutkevichinella archangelskyi Schleifer, 1973 also shows affinity to the present material in carapace shape but the present species differs by the inclination of the dorsal margin, the overlap of the left valve around the complete free margin and the reverse overlap at the dorsal margin.

The present specimens are assumed to be conspecific with material from the uppermost Permian of the Dolomites (Bulla section) (Crasquin et al., 2008) determined as 'Callicythere mazurensis (Styk, 1972)'. Callicythere mazurensis sensu Styk (1972) shows a symmetrically rounded anterior margin and the anterior margin of $C$.? seisensis is clearly asymmetrical in the anterodorsal portion. In dorsal view the carapace of $C$. mazurensis is not inflated posteriorly and does not show sexual dimorphism. Styk (1972) also reports a small sulcus in the central part and a short ridge along the ventral margin, which do not occur on C.? seisensis.

Family unknown

Gen. et sp. indet. 1

(P1. 3, figs 3-7)

Material. 4 carapace, 41 valves.

Stratigraphic and geographical range. Upper Bellerophon Formation, Casera Razzo Member (samples 13, 14), late Changsingian, Seis (Siusi) section, South Tyrol, Italy.

Remarks. The present species is characterized by a fine irregular reticulate ornamentation of the lateral surface. The size of the reticulation meshes is greatest in the central part of the lateral surface and decreases towards the peripheral parts. In lateral view the species is subrectangular and comprises specimens with a relatively slender outline and specimens with a stouter outline. This variability in lateral outline may be due to sexual dimorphism but this suggestion cannot be proved because of poor preservation. The species shows some affinity to the Rhaetian genus Rhombocythere with regard to the type of ornamentation and outline in lateral view. In contrast to this genus the present specimens do not have a flattened venter and no carina on the ventral and dorsal margins. A comparison of internal features is not possible because these are not accessible for the present species. Other similar species are not reported in literature on Permian and Triassic ostracods and the present species may thus represent a new genus.

\section{CONCLUSIONS}

The Late Permian (Changsingian) Casera Razzo Member of the Bellerophon Formation at Seis (Dolomites) yielded low diversity ostracod assemblages which are dominated by Cavellina bellerophonella Crasquin, 2008, Sargentina postacuta (Zalanyi, 1974), Knoxiella ventrospinosa Crasquin, 2008 and Callicythere? seisensis n. sp. They inhabited a protected inner lagoonal environment which was characterized by minor sea-level changes and salinity fluctuations. A monotypic assemblage of large and thick-shelled representatives of Paraparchitidae is indicative of a more turbulent eulittoral palaeoenvironment which was probably located in the external part of the lagoon. The low number of species common with Late
Permian ostracod assemblages of other localities is a result of the environmental instability which inhibited the immigration of species from the open-marine Tethyan realm. Callicythere? seisensis n. sp. and Arqoviella? dolomitica n. sp. show some affinity to the genera Lutkevichinella and Pulviella, respectively, which appear in the Early Triassic. C.? seisensis n. sp. and A.? dolomitica n. sp. may thus represent early precursors of these Triassic taxa.

\section{ACKNOWLEDGEMENTS}

The critical review of the manuscript by Ian Boomer and Alan Lord and their valuable comments are gatefully acknowledged. Rainer Brandner (Innsbruck) and Christoph Korte (Copenhagen) are thanked for constructive discussions.

\section{Manuscript received 9 May 2011 \\ Manuscript accepted 3 August 2011}

Scientific Editing by Alan Lord

\section{REFERENCES}

Accordi, B. 1957. Contributo alla coscenza del Permiano medio-superiore della zona di Redagno (Bolzano). Annali dell'Università Ferrara, N.S., 3(2): 37-47.

Becker, G. \& Bless, M.J.M. 1990. Biotope-indicative features in Palaeozoic ostracodes: A global phenomenon. In: Whatley, R. \& Maybury, C. (Ed.), Ostracoda and Global Events. Chapman \& Hall, London, 421-436.

Bennett, C. 2008. A review of the Carboniferous colonisation of nonmarine environments by ostracods. Senckenbergiana lethaea, 88(1): $37-46$.

Bless, M.J.M. 1983. Late Devonian and Carboniferous ostracode assemblages and their relationship to the depositional environment. Bulletin de la Société belge de Gèologie, 92(1): 31-53.

Bless, M.J.M., Streel, M. \& Becker, G. 1987. Distribution and palaeoenvironment of Devonian to Permian ostracode assemblages in Belgium with reference to some Late Famennian to Permian marine nearshore to "brackish-water" assemblages dated by miospores. Annales de la Société géologique de Belgique, 110: 347-362.

Boomer, I., Horne, D.J. \& Slipper, I. 2003. The use of ostracods in palaeoenvironmental studies, or what can you do with an ostracod shell? Paleontological Society Papers, 9: 153-179.

Bosellini, A. \& Hardie, A.L. 1973. Depositional theme of a marginal marine evaporite. Sedimentology, 20: 5-27.

Coryell, H.N. 1928. Some new Pennsylvanian ostracoda. Journal of Paleontology, 2(4): 377-281.

Crasquin, S., Perri, M.C., Nicora, A. \& De Wever, P. 2008. Ostracods across the Permian-Triassic boundary in western Tethys: The Bulla Parastratotype (Southern Alps, Italy). Rivista Italiana di Paleontologia e Stratigrafia, Milano, 114(2): 233-262.

Crasquin, S., Forel, M.-B., Qinglai, F., Aihua, Y., Baudin, F. \& Collin, P.Y. 2010a. Ostracods (Crustacea) through the Permian-Triassic boundary in South China: the Meishan stratotype (Zhejinag Province). Journal of Systematic Palaeontology, 8(3): 331-370.

Crasquin, S., Sudar, M.N., Jovanovic, D. \& Kolar-Jurkovsek, T. 2010b. Upper Permian ostracode assemblage from the Jadar Block (Vardar Zone, NW Serbia). Annales Géologiques de la Péninsule Balkanique, 71: $23-35$.

Crasquin-Soleau, S. \& Kershaw, S. 2005. Ostracod fauna from the PermianTriassic boundary interval of South China (Huaying Mountains, eastern Sichuan Province): palaeoenvironmental significance. Palaeogeography, Palaeoclimatology, Palaeoecology, 217: 131-141.

Crasquin-Soleau, S., Broutin, J., Roger, J. et al. 1999. First ostracode fauna from the Upper Permian of Oman (Kuff Formation). Micropaleontology, 45(2): 163-182. 
Crasquin-Soleau, S., Marcoux, J., Angiolini, L., Nicora, A. \& Bertho, Y. 2004. New ostracod fauna from Permian-Triassic boundary in Turkey (Taurus, Antalya Nappes). Micropaleontology, 23: 67-76.

Crasquin-Soleau, S., Vaslet, D. \& Le Nindre, Y.M. 2005. Ostracods from Permian-Triassic boundary in Saudi Arabia (Khuff Formation). Palaeontology, 48(4): 853-868.

Delo, D.M. 1930. Some Upper Carboniferous ostracoda from the Shale Basin of Western Texas. Journal of Paleontology, 4(2): 152-178.

Farabegoli, E., Levanti, D. \& Perri, M.C. 1986. The Bellerophon Formation in the southwestern Carnia. Lavardet-Rioda and Casera Federata sections. In: Italian IGCP Project 203 (Eds), Field Conference on Permian and Permian-Triassic boundary in the south-alpine segment of the western Tethys, and additional regional reports. Field Guidebook, Brescia, 4-12 July, 69-71.

Farabegoli, E., Perri, M.C. \& Posenato, R. 2007. Environmental and biotic changes across the Permian-Triassic boundary in western Tethys: The Bulla parastratotype, Italy. Global and Planetary Change, 55: 109-135.

Gerry, E., Honigstein, A., Derin, B. \& Flexer, A. 1987. Late Permian ostracodes of Israel. Taxonomy, distribution, and paleogeographical implications. Senckenbergiana Lethaea, 68(1/4): 197-223.

Jones, P.J. 1970. Marine ostracoda (Palaeocopa, Podocopa) from the Lower Triassic of the Perth Basin, Western Australia. Bureau of Mineral Resources, Geology and Geophysics, Australia, Palaeontological Papers, Bulletin, 108(6): 115-143.

Jones, T.R. 1859. Notes on the species. In Kirkby, J.W. (1859), On Permian entomostracan from the Shell-Limestone of Dunham, with notes on the species by T. Rupert Jones. Transactions of the Tyneside Naturalist' Field Club, 4(1885-1860; 2): 122-171.

Kilenyi, T.I. 1971a. The problems of ostracod eceology in the Thames estuary. In: Neale, J.W. (Ed.), The Taxonomy, Morphology and Ecology of recent Ostracoda. Oliver \& Boyd, Edinburgh, 250-265.

Kilenyi, T.J. 1971b. Some basic questions in the palaeoecology of ostracods. Bulletin du Centre de Recherches de Pau-SNPA, 5: 31-44.

Kotchetkova, N.M. \& Gusseva, E.A. 1972. Rannepermskie ostrakody yuzhnovo y srednevo priuralja. Akademija Nauk SSSR, Baschkirskii Filial Institut Geologii, Isdatelstvo Nauka, Moscow 1972, 1-180.

Kozur, H. 1981. Einige neue Ostracoden-Arten aus dem Oberperm des Bükk-Gebirges (Nordungarn). Radovi Geoinstituta (Proceedings of Geoinstitute), 15: 199-204.

Kozur, H. 1985a. Neue Ostracoden-Arten aus dem oberen Mittelkarbon (höheres Moskovian), Mittel- und Oberperm des Bükk-Gebirges (N-Ungarn). Geologisch-Paläontologische Mitteilungen Innsbruck, Sonderband 2: 1-145.

Kozur, H. 1985b. Biostratigraphic evaluation of the Upper Paleozoic conodonts, ostracods and holothurian sclerites of the Bükk Mts. Part II: Upper Paleozoic ostracods. Acta Geologica Hungarica, 28(3-4): 225-256.

M'Coy, F. 1844. A synopsis of the characters of the Carboniferous limestone fossils of Ireland. Dublin, 1-8: 5-207.

Noé, S. 1987. Facies and Paleogeography of the marine Upper Permian and of the Permian-Triassic boundary in the Southern Alps (Bellerophon Formation, Tesero Horizon). Facies, 16: 89-142.

Oertli, H.J. 1971. The aspect of ostracode faunas - A possible tool in petroleum sedimentology. Bulletin du Centre de Recherches de Pau-SNPA, 5: $137-151$.

Pasini, M. 1981. Nota preliminare su una fauna ad ostracodi die livelli superiori della Formatione a Bellerophon delle Dolomiti. Rivista Italiana di Paleontologia e Stratigraphia, 87(1): 1-22.

Pittau, P. 2001. Correlation of the Upper Permian sporomorph complexes of the Southern Alps with the Tatarian complexes of the stratotype region. In: Cassinis, G. (Ed.), Permian continental deposits of Europe and other areas. Regional Reports and Correlations. Natura Bresciana, 25: $109-116$.

Schleifer, A.G. 1973. Ostrakody iz otlozheniy Triasa prikaspiyskoy vpadiny. [Ostracods from Triassic deposits of the Precaspian Trough]. Trudy Moskovskogo Instituta Neftekhimicheskoy I Gazovoy Promyshlennosti Imeni Akad. I.M. Gubkina (Minkh I GP), 103: 1-43.

Shi, C.G. \& Chen, D.Q. 2002. Late Permian ostracodes from Heshan and Yishan of Guangxi. Bulletin of Nanjing Institute Geology and Palaeontology, Academia Sinica, 15: 47-129.

Siegert, S., Kraus, S.H., Mette, W., Struck, U. \& Korte, C. 2011. Organic carbon isotope values from the Late Permian Seis/Siusi succession (Dolomites, Italy): Implications for palaeoenvironmental changes. Fossil Record, 14, 2: 207-217.

Sohn, I.G. 1960. Paleozoic species of Bairdia and related genera. US Geological Survey Professional Papers, 330A: 1-105.

Sohn, I.G. 1968. Triassic ostracodes from Makhtesh Ramon, Israel. State of Israel, Ministry of Development, Jerusalem, Geological Survey Bulletin, 44: 1-71.

Sohn, I.G. 1970. Early Triassic marine ostracodes from the Salt Range and Surghar Range, West Pakistan. In: Kummel, B. \& Teichert, C. (Eds), Stratigraphic Boundary Problems: Permian and Triassic of West Pakistan. University of Kansas, Department of Geology, Special Publication, 4: 193-206.

Starozhilova, N.N. 1968. Paleontologicheskiy ocherk. In: Lipatova, V.V. \& Starozhilova, N.N. (Eds), Stratigrafiya I Ostrakody Triasovkh Otlozheniy Saratovskogo Zavolzhya [Stratigraphy and Ostracodes of Triassic Deposits of the Saratov Area to the East River of Volga]. Moscow: 1-192.

Styk, O. 1972. Some more important new species of foraminifers and ostracods from the Triassic deposits of Poland. Kwartalnik Geologiczny, 16(4): $867-885$.

Ulrich, E.O. \& Bassler, R.S. 1906. New American Paleozoic Ostracoda. Notes and descriptions of Upper Carboniferous genera and species. Proceedings of the United States National Museum, 30(1446): 149-164.

Vinn, O. 2010. Adaptive strategies in the evolution of encrusting tentaculitoid tubeworms. Palaeogeography, Palaeoclimatology, Palaeoecology, 292: 211-221.

Wang, S.-Q. 1978. Late Permian and Early Triassic ostracods of western Guizhou and northeastern Yunnan. Acta Palaeontologica Sinica, 17(3): 277-308.

Wei, M. 1981. Early and Middle Triassic Ostracods from Sichuan. Acta Palaeontologica Sinica, 20(6): 501-507.

Whatley, R. 1983a. Simple procerdures for enhancing the use of Ostracoda in Palaeoenvironmental analysis. Norwegian Petroleum Directorate, Bulletin, 2: 129-146.

Whatley, R. 1983b. The application of ostracoda to palaeoenvironmental analysis. In: Maddocks, R.F. (Ed.), Applications of Ostracoda. University of Houston Geoscience, Houston, 51-77.

Whatley, R. 1988. Population structure of ostracods: some general principles for the recognition of palaeoenvironments. In: DeDeckker, P., Colin, J.P. \& Peypouquet, J.P. (Eds), Ostracoda in the Earth Sciences, Elsevier, Amsterdam, 245-256.

Williams, M., Leng, M.J., Stephenson, M.H. et al. 2006. Evidence that Early Carboniferous ostracods colonised coastal flood plain brackish water environments. Palaeogeography, Palaeoecology, Palaeoclimatology, 230: 299-318.

Zaspelova, V.S. 1953. In Egorov, V.G. (Ed.), Indivisiinae - novoe Podsemeystvo kloedenellidae Franskogo Yarusa Russkoy Platformy [Indivisiinae - A new subfamily of Kloedenellidae from the Frasnian Stage of the Russian platform]. Trudy VNIGRI, Paleontologicheskiy Sbornik, 1: 5-21, Moscow. 


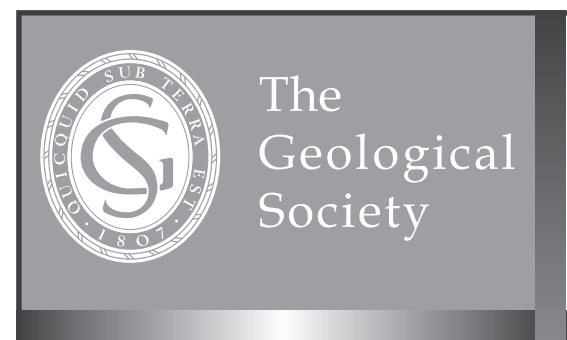

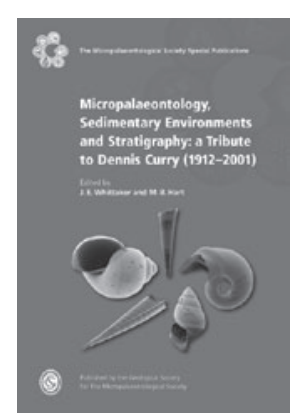

-ISBN: 978-1-86239-305-9

- September 2010

-304 pages

-Prices:

List: $\mathbf{f 9 0 . 0 0 / U S \$ 1 8 0 . 0 0}$

GSL: $f 54.00 / U S \$ 108.00$

TMS: $\mathbf{f 4 5 . 0 0 / U S \$ 9 0 . 0 0}$

Online bookshop code:

TMSO04
- The Micropalaeontological Society Series (TMS)

\section{Micropalaeontology, Sedimentary Environments and Stratigraphy: A Tribute to Dennis Curry (1912-2001)}

\author{
Editors: J. E. Whittaker \& M. B. Hart
}

Dennis Curry was a remarkable polymath and philanthropist, leading a double-life as one of the UK's most gifted amateur geologists, whilst at the same time being an extremely successful businessman (as Managing Director of Currys Ltd). This Festschrift, authored by friends and specialists from Britain and France, pays tribute to his often seminal research as well as exhibiting the wide range of his geological interest. It contains 12 chapters and covers several differing aspects of micropalaeontology (pteropods, diatoms and especially foraminifera), Strontium Isotope Stratigraphy, Hampshire Basin stratigraphy and palaeogeography, as well as major contributions on English Channel sedimentology and the great faunal turnover affecting mammals at the Eocene-Oligocene boundary. A scientific appreciation of Dennis Curry, 'the professional amateur', with recollections of former colleagues at University College, London (where he was Visiting Professor), together with an assessment of the valuable collections he established and donated to The Natural History Museum, are also included. Copiously illustrated, this book is a must for all geologists.

Postage: UK: $+5 \%$ ( $£ 4.50$ minimum) Europe: $+15 \%$ ( $£ 9.00$ minimum) Rest of world: $+15 \%$ ( $€ 13.50$ minimum) All prices and postage valid until 31 December 2011. Please allow up to 28 days for delivery of in stock items in the UK. Parcels to Europe and Rest of World are sent by surface mail and can take 6 to 12 weeks to arrive. (Air or courier rates available on request).

Please order from: Geological Society Publishing House, Unit 7 Brassmill Enterprise Centre, Brassmill Lane, Bath BA1 3JN, UK Tel: +44 (0)1225 445046 Fax: +44 (0)1225 442836 Email: sales@geolsoc.org.uk Online bookshop: www.geolsoc.org.uk/bookshop Society Web Site: www.geolsoc.org.uk

For full details see the Online Bookshop: www.geolsoc.org.uk/bookshop
The Geological Society's Lyell Collection: journals, Special Publications and books online. For more information visit www.geolsoc.org.uk/LyellCollection 